Columbia Law School

Scholarship Archive

1996

\title{
The Role of Firearms in Violence "Scripts": The Dynamics of Gun Events among Adolescent Males
}

\author{
Deanna L. Wilkinson \\ Jeffrey Fagan \\ Columbia Law School, jfagan@law.columbia.edu
}

Follow this and additional works at: https://scholarship.law.columbia.edu/faculty_scholarship

Part of the Criminal Law Commons, Juvenile Law Commons, Law and Race Commons, and the Sociology Commons

\section{Recommended Citation}

Deanna L. Wilkinson \& Jeffrey Fagan, The Role of Firearms in Violence "Scripts": The Dynamics of Gun Events among Adolescent Males, 59 LAW \& CONTEMP. PROBS. 55 (1996).

Available at: https://scholarship.law.columbia.edu/faculty_scholarship/2263

This Article is brought to you for free and open access by the Faculty Publications at Scholarship Archive. It has been accepted for inclusion in Faculty Scholarship by an authorized administrator of Scholarship Archive. For more information, please contact scholarshiparchive@law.columbia.edu. 


\title{
THE ROLE OF FIREARMS IN VIOLENCE "SCRIPTS": THE DYNAMICS OF GUN EVENTS AMONG ADOLESCENT MALES
}

\author{
DEANNA L. WILKINSON* AND JEFFREY FAGAN**
}

\section{INTRODUCTION}

In recent years, the use and deadly consequences of gun violence among adolescents has reached epidemic proportions. At a time when national homicide rates are declining, the increasing rates of firearm deaths among teenagers is especially alarming. Deaths of adolescents due to firearm injuries are disproportionately concentrated among nonwhites, and especially among African-American teenagers and young adults. Only in times of civil war have there been higher within-group homicide rates in the United States. There appears to be a process of self-annihilation among male African-American teens in inner cities that is unprecedented in American history. Unfortunately, few studies have examined these sharp increases in gun fatalities among young males.

This article attempts to contribute to the scant literature by examining the role of firearms in violent events among adolescent males. First, using an eventbased approach, it suggests a framework for explaining interactions that involve adolescents and firearms. Events are analyzed as "situated transactions," including rules that develop within specific contexts, the situations where weapons are used, the motivations for carrying and using weapons, and the personality "sets" of groups where weapons are used. There are "rules" that govern how disputes are settled, when and where firearms are used, and the significance of firearms within a broader adolescent culture. This approach does not deny the importance of the individual attributes that bring people to situations, but it recognizes that once in the situation, other processes shape the outcomes of these events.

This article describes how violence "scripts" are invoked, how scripts may limit the behavioral and strategic options for resolving disputes, and how the presence of firearms may influence which scripts are invoked. Because violence generally is a highly contextualized event, this article also focuses on how specific contexts shape decisions by adolescents to carry or use weapons, and

\footnotetext{
Copyright $\odot 1996$ by Law and Contemporary Problems

* Doctoral candidate, School of Criminal Justice, Rutgers University; staff associate, Center for Violence Research and Prevention, Columbia University.

** Visiting Professor, School of Public Health, Columbia University; Professor, School of Criminal Justice, Rutgers University.
} 
how violence "scripts" are developed and shaped through diffusion within closed social groups.

This article then reviews the patterns of firearm use among adolescents over time and in specific eras and identifies factors that seem to have contributed to the recent escalation and the present day crises. It then provides an analysis of recent, influential surveys. The literature on guns and adolescents is characterized by broad surveys that gauge how often students bring weapons to school, and how their outlooks have been affected by the presence of firearms. ${ }^{1}$ Most of these studies suffer from selection biases by excluding dropouts and institutionalized youths with higher rates of violence and weapons use. ${ }^{2}$ Research on inner-city adolescents has often confounded firearm use with other forms of adolescent violence (for example, physical and sexual assault or robbery) or co-morbid problem behaviors (for example, substance use, school dropout, or teenage pregnancy). But there is no evidence that firearm use by adolescents is part of a generalized pattern of adolescent violence or a maladaptive developmental outcome. In fact, few studies have distinguished adolescents who are violent from those violent adolescents who carry or use firearms.

Perhaps most importantly, no studies have examined the specific role of firearms in violent events. ${ }^{3}$ The 1993 survey by LH Research suggests that the number of events where guns are used are a small fraction of the number of events where guns are present. ${ }^{4}$ Although several studies attribute violence to the dynamics and contingencies in contexts such as gang conflicts, drug markets, domestic disputes, or robberies, few studies have addressed the dynamics or antecedents of firearm use in inner cities among adolescents or young males, especially the mechanisms that escalate gun possession to gun use. ${ }^{5}$ That is,

1. See, e.g., JOSEPH F. SHELEY \& JAMES D. WRIGHT, NAT'L INSTITUTE OF JUSTICE, GUN ACQUiSITION AND POSSESSION IN SELECTED JUVENILE SAMPLES (Dec. 1993); LH Research, A Survey of Experiences, Perceptions, and Apprehensions About Guns Among Young People in America (1993) (on file with School of Public Health, Harvard University).

2. Jeffrey Fagan et al., Violent Delinquents and Urban Youths, 24 CRIMINOLOGY 445 (1986).

3. These studies often confound firearms with other weapons, and confound weapons use generally with other forms of violence. See, e.g., DelbERT S. ElliotT ET AL., MULTIPLE PROBLEM YOUTH: DElinquenCy, DRUGS, AND MENTAL HeAlTh PROBLEMS 1 (1989). Moreover, the low base rates of violence in these studies limits efforts to explain the use of firearms or other weapons. Violence in these studies is more often concentrated in inner-cities, leading to a potential confounding of individual characteristics with social area effects. Robert J. Sampson \& William J. Wilson, Race, Crime and Urban Inequality, in CRIME AND INEQUALITY 37-54 (John Hagan and Ruth D. Peterson eds., 1995).

4. LH Research, supra note 1.

5. Philip J. Cook, A Strategic Choice Analysis of Robbery, in SAMPLE SURVEYS OF THE VICTIMS OF CRIME 186 (W. Skogan ed., 1976) (finding that guns are a means to pursue more lucrative targets for victimization); Jeffrey Fagan, Set and Setting Revisited: Influences of Alcohol and Illicit Drugs on the Social Context of Violent Events, in ALCOHOL AND INTERPERSONAL VIOLENCE: FOSTERING Multidisciplinary PERSPECTIVES 161, 163, 169-72 (Susan E. Martin ed., 1993). The social and cultural landscape of inner-city neighborhoods described by Anderson provides further support for research focused on situational transactions. Elijah Anderson, The Code of the Streets, THE ATLANTIC MONTHLY, May 1994; ElJuA ANDERSON, STREETWISE: RACE, ClASS, AND CHANGE IN AN URBAN COMMUNITY (1990); GEOFFREY CANADA, FIST, KNIFE, STICK, GUN: A PERSONAL HISTORY OF VIOLENCE IN AMERICA (1995). Social networks within neighborhoods where these events are likely 
research on adolescent firearm use has not yet analyzed the interactions of the individual characteristics involved, the interpersonal transactions and interactions between the parties, or how the presence of guns affects the outcomes of these interactions. And no studies have focused on specific social or neighborhood contexts that also shape the outcomes of putative violent events. Such an approach seems necessary to explain the increase in firearm fatalities among young African-Americans and to locate the problem in the specific contexts where these events occur.

This article then presents an analysis of our research, applying an eventbased approach to provide a conceptual framework. The preliminary results of the research will demonstrate the role weapons have in adolescent violence, and how the presence of firearms contributes to increasingly alarming homicide rates among inner-city adolescents. We will then follow the presentation of our analysis with a section discussing ideas for prevention and intervention to curb gun-related violence among inner-city males.

\section{II}

\section{THEORIES OF VIOLENT EVENTS: TOWARD AN INTEGRATED FRAMEWORK}

Violence researchers have come to understand dispute-related violent events as a process of social interactions with identifiable rules and contingencies. ${ }^{6}$ Numerous studies have applied this framework with respect to violence focusing on the interactional dynamics of situated transactions. ${ }^{7}$ The processual nature of violent, interpersonal transactions is both rule oriented and normative. ${ }^{8}$ It is through these processes and contingencies that individual characteristics such as "disputatiousness" are channeled into violent events. Violent behavior can

to occur are adaptive organizational responses to specific social and cultural contexts. The social exchanges within these networks provide specific motivations and social values that may limit the range of behavioral choices once conflicts arise. Anderson, The Code of the Streets, supra, at 82.

6. Felson distinguishes "predatory" violence from dispute-related violence, suggesting that there are processual factors in dispute-related violence that are not evident in "predatory" assaults. Richard B. Felson, Predatory and Dispute-Related Violence: A Social Interactionist Approach, in 5 RoUTINE ACTIVITY AND RATIONAL CHOICE, ADVANCES IN CRIMINOLOGICAL THEORY 104-05 (Ronald V.Clarke \& Marcus Felson eds., 1993). Predatory violence is defined as physical aggression committed without provocation while dispute-related violence involves a reaction to some alleged wrong. Id. However, Katz suggests that even the most seemingly irrational violent acts have a logical and predictable sequence. JACK KATZ, SEdUCTIONS OF CRIME: MORAL AND SENSUAL ATTRACTIONS OF DOING EVIL 9-10 (1988). There may be disputes involved between the aggressor and the victim, but there appears to be no interaction between the two parties preceding the violent act. In these cases, the victim may be a proxy, surrogate or symbolic target for the other disputant. Id.

7. Richard B. Felson \& Henry J. Steadman, Situational Factors in Disputes Leading to Criminal Violence, 21 CRIMINOLOGY 59-60 (1983); David F. Luckenbill, Criminal Homicide as a Situated Transaction, 25 SOC. PROBLEMS 176 (1977); Richard B. Felson, Impression Management and the Escalation of Aggression and Violence, 45 SOC. PSYCHOL. Q. 245 (1982); ANNE CAMPBELL, THE GIRLS IN THE GANG: A REPORT FROM NEW YORK CITY 28-32 (1984); David F. Luckenbill \& Daniel P. Doyle, Structural Position and Violence: Developing a Cultural Explanation, 27 CRIMINOLOGY $422-23$ (1989); William Oliver, THE Violent Social World of BLACK MEN 138-40 (1994).

8. Derek Cornish, Crimes as Scripts, presented at the Second Annual Seminar on Environmental Criminology and Crime Analysis (May 26-28, 1993) (unpublished manuscript, on file with the author). 
be viewed as a method of communicating social meanings within contexts where such action is either expected or at least tolerated.

This article argues that the presence of firearms presents a unique contingency that shapes decisionmaking patterns of individuals. The presence of firearms influences decisions both in social interactions with the potential for becoming disputes and also within disputes that have already begun. ${ }^{9}$ The influence on decisionmaking is compounded by the social contexts in which firearm injuries are concentrated: inner-city neighborhoods characterized by extensive "resource deprivation." 10 The article specifies two socialization processes that have converged in these areas to create a unique influence of firearms: the emergence of a "street code" that shapes perceptions of grievances and the norms of their resolution, ${ }^{11}$ and an "ecology of danger" where social interactions are perceived as threatening or lethal, and where individuals are normatively seen as harboring hostile intent and the willingness to inflict harm. The latter is the product of three successive generations in inner cities who grew up in epochs of high rates of homicide and firearm injuries.

\section{A. Symbolic Interactionism and Social Interaction}

Symbolic interactionism offers a useful perspective for examining transactional aspects of violent behavior among two or more individuals. According to Herbert Blumer, "human interaction is mediated by the use of symbols, by interpretation, or by ascertaining the meaning of one another's actions."12 Human action is processual and begins with observation/sensation that results in an "indication to the self," which is noted and interpreted in order to construct a proper response. It is through this process of self-indication that an individual digests information and begins to formulate a decision for his or her future action. One of the central ideas of symbolic interactionism is "taking each other into account." Blumer has stated that

taking another person into account means being aware of him, identifying him in some way, making some judgement or appraisal of him, identifying the meaning of his action, trying to find out what he has on his mind or trying to figure out what he intends to do. Such awareness of another person in this sense of taking him and his acts into consideration becomes the occasion for orienting oneself and for the direction of one's own conduct. One takes the other person and his action into account not merely at the point of initial contact, but actually throughout the period of interaction. ... Perceiving, defining and judging the other person and his action and organizing oneself in terms of such definitions and judgements constitute a continuing or running process. ${ }^{13}$

9. See Jeffrey Fagan \& Deanna L. Wilkinson, Situational Contexts of Gun Use Events Among Young Males in the Inner City (proposal submitted to the National Science Foundation) (on file with authors).

10. Kenneth Land et al., Structural Covariates of Homicide Rates, 95 AM. J. Soc. 922, 951 (1990).

11. See, e.g., Anderson, The Code of the Streets, supra note 5, at 82.

12. HERBERT BLUMER, SYMBOLIC INTERACTIONISM: PERSPECTIVE AND METHOD 79 (1969).

13. Id. at 109. 
Blumer has further noted that an individual also takes his or her own actions into account and makes interpretations. ${ }^{14}$

In his work, Erving Goffman offers many insights into the dynamic social processes of human interaction. Early in his career, Goffman studied the ways in which a person presents an image of himself to others and develops a view of others as social actors. ${ }^{15}$ In addition, he studied the ritualistic aspects of social interaction in a variety of different social contexts. Defining interaction as "the reciprocal influence of individuals upon one another's actions when in one another's immediate physical presence," Goffman concluded that the actor could manipulate the impression received by projecting a certain definition of the situation he enters. ${ }^{16}$ Goffman explained that "first impressions" were crucial for determining the next stage in most interactions. Other participants in the situations will most often confirm the original definition of the situation consistent with how others around them react or register the event. Under this theory, individual behavior is "scripted" to the extent that scripts are used to convey the kind of impression (or situational identity) an actor wants others to perceive. The importance of status and reputation in this social context influences the scripts an individual may choose when confronted with a dispute on the streets. One could argue that based on whatever limited knowledge is available at the start of the event, an individual will choose a script that casts him or her in the best light.

Goffman later began to focus on linking the micro-dynamics of social interaction with the macro-level forces working to structure such interactions. People create meaning in face-to-face interactions by drawing on local agreements, definitions, and understandings that are upheld during an event. ${ }^{17}$ The lesson of an event may continue into the future as the parties have future contact. In an inner-city context, the scope of the repertoire available for the actor is quite limited. ${ }^{18}$ The code of the streets operates both at the micro and macro levels through social interaction, cumulative definitions of conflict situations, and replication support for the code. ${ }^{19}$

\section{B. Violence and the Social Interactionist Perspective}

The social interactionist perspective also emphasizes the role of social interaction over other "personality" explanations in aggressive behavior. ${ }^{20}$ It

14. Id. at 111 .

15. Goffman describes the concepts of "character contests" and "impression management." ERVING GOFFMAN, INTERACTION RITUAL 218-19, 238-57 (1967).

16. ERVING GoffMAN, THE PRESENTATION OF SELF IN EVERYDAY LIFE 15 (1959).

17. Erving Goffman, The Interaction Order, 48 AM. SOC. REV. 1-17 (1983).

18. This is described in detail by Anderson. Anderson, The Code of the Streets, supra note 5, at 86-88.

19. Id. at 80,86 .

20. See, e.g., Fagan, supra note 5 at 179-180, on the influence of set and setting on the outcomes of disputes where the actors have been drinking. Feison also explains different outcomes of barroom disputes (brawls versus crying in one's beer) as the interaction of personality "set" of the actors and 
interprets all aggressive behavior as goal oriented or instrumental, that is, as an attempt to achieve what is valued. Social interaction is examined in terms of a rational choice or decisionmaking model. Three main goals of aggressive actions have been identified: (1) to compel and deter others; (2) to achieve a favorable social identity; and (3) to obtain justice. ${ }^{21}$ An interactionist perspective is concerned with the actor's point of view. The interactionist approach focuses on describing the factors that produce conflict and those that inhibit it.

According to James Tedeschi and Richard Felson, all violence is goaloriented behavior, and such behavior is either motivated by the desire to achieve some outcome (terminal values) or is a means of acting (procedural values). ${ }^{22}$ It is the valued outcome (goal) that motivates the use of violence and not some involuntary response to aversive stimuli. Tedeschi and Felson explain that the means of achieving the goal are also valued and play a part in fulfilling the objectives of the actor. ${ }^{23}$

Felson and Tedeschi articulate three assumptions of the social interactionist perspective: (1) harm-doing and the threat of harm are motivated by the desire to achieve personal goals; (2) situational factors should be emphasized, including interpersonal relationships between actors, the social interchange between actors, and third parties; and (3) the perceptions, judgments, expectations, and values of the perpetrator need to be examined. ${ }^{24}$ Consistent with the rational choice perspective, they argue that a violent action involves a sequence of decisions and that an actor evaluates alternatives before carrying out a violent action. Four elements of decisions were outlined: the value of the outcome; the expectations of success in reaching the goal; the value of the costs; and the expectations of the costs. ${ }^{25}$ Costs and the presence of third parties can inhibit violence. ${ }^{26}$ The actor makes a choice to engage in violent behavior because it seems to be the best alternative available in the situation.

Felson and Tedeschi also explain that a decisionmaker is typically operating under some type of decision rule. They described two rules: the "minimax" principle (maximum benefits and minimize costs) and the "satisficing" principle (good enough). ${ }^{27}$ A decisionmaking framework thus examines what goes on

the social control mechanisms present in the "setting." Richard B. Felson et al., Barroom Brawls: Aggression and Violence in Irish and American Bars, in VIOLENT TRANSACTIONS 153, 163-65 (Anne Campbell \& John Gibbs eds., 1986).

21. KATZ, supra note 6, at 18-19; Felson, supra note 6, at 105.

22. JAMES T. TEDESCHI \& RiChARD B. Felson, ViolenCE, AggRession, and COERCIVE ACTIONS 22 (1994) (departing greatly from previous work in the area of vioience research primarily because of the claim that all violent behaviors (coercive actions) are instrumental or goal-oriented behavior).

23. Id.

24. Richard B. Felson \& James T. Tedeschi, A Social Interactionist Approach to Violence: Crosscultural Applications, in INTERPERSONAL VIOLENT BEHAVIORS: SOCIAL AND CULTURAL ASPECTS 15354 (Ruback Barry \& Neil Alan Weiner eds., 1995).

25. Id. at $154-55$.

26. Id. at 154,162 .

27. TEDESCHI \& FELSON, supra note 22, at 182. 
in the actor's mind during a violent event in terms of weighing the rewards and costs of an action while in pursuit of a desired outcome. If an actor determines that the benefits outweigh the costs of a violent action, then he chooses to engage in the action. ${ }^{28}$ This decisionmaking process thus becomes extremely complicated in a social environment where the choices in handling a situation may be limited to "takin' care of your business" (with a gun) or losing face on the street. ${ }^{29}$

\section{Violence as Situated Transactions}

David Luckenbill and Daniel Doyle have argued that interpersonal disputes are the products of three successive events: "naming," "claiming," and "aggressing." 30 At the naming stage, the first actor identifies a negative outcome as an injury caused by the second actor (assigning blame). ${ }^{31}$ At the claiming stage, the injured party expresses his grievance and demands reparation from the adversary. It is the final stage that determines whether or not the interaction is transformed into a dispute. According to Luckenbill and Doyle, "disputatiousness" is defined as the likelihood of naming and claiming, and aggressiveness is defined as the willingness to preserve and use force to settle the dispute. They claim that violence is triggered by norms of the code of personal honor and that differential disputatiousness and aggressiveness would depend on the situation. ${ }^{32}$ This article argues that increased availability of guns, especially among adolescents, changes these processes in important ways that are not fully understood at this time. The stages of violent events are altered by the presence, expectancies, and lethal nature of firearms in specific social contexts.

Later research has used a similar event-centered approach to examine the interactive processes leading to criminal violence. ${ }^{33}$ Using official data from 159 incidents of homicide and assault (where suspects were incarcerated), Felson and Steadman developed a detailed action-unit coding scheme for the data. They found that the incidents tended to follow systematic patterns, beginning with identity attacks, followed by attempts and failures to influence the

28. Felson \& Tedeschi, supra note 24 , at $154-55$.

29. Id. at 156 .

30. Luckenbill \& Doyle, supra note 7, at 419, 423 (relying on Luckenbill, supra note 7).

31. Id.

32. Id. at 425 . This conceptualization closely resembles Goffman's "character contest" used by Luckenbill to examine violent transactions resulting in homicide. Luckenbill, supra note 7, at 177. According to Luckenbill and Doyle, a character contest goes something like this:

$[O]$ ne begins by attacking another's identity, challenging his or her claim to a valued position in a situation. The other defines the attack as offensive and retaliates, attempting to restore identity either by threatening to injure the challenger if he or she does not back down or by using force to make the challenger if he or she does not withdraw or by using limited force to make the challenger withdraw. Rather than back down and show weakness, the challenger maintains or intensifies the attack. Fearing a show of weakness and loss of face, and recognizing that peaceful or mildly aggressive means have failed to settle the dispute, one or both mobilize available weapons and use massive force, leaving one dead or dying.

Luckenbill \& Doyle, supra note 7, at 423.

33. Felson \& Steadman, supra note 7 , at 60. 
opponent, then verbal threats, and finally, ending in physical attack. Retaliation, escalation, and aggressiveness of the victim were found to be important factors. This study, albeit limited methodologically, illustrates the usefulness of a processual analysis of violent events. Detailed narratives on incidents, offered voluntarily without prejudicial motive, both discovered by law enforcement and those that go unnoticed, may provide insights that previous research using official data could not.

An even later study used detailed narratives of violent confrontations between black males in bars and bar settings. ${ }^{34}$ In a study of forty-one adult African-American males, a five-stage sequence of events was observed that is similar to Felson and Steadman's previous classification. The first stage was characterized by a perception that an antagonist committed an act that represented a potential threat to the respondent's manhood, physical safety, and/or reputation..$^{35}$ The second stage involved an attempt to clarify the antagonist's intentions. This step also included an attempt to confirm one's definition of the situation. Stage three was the development of a plan of action and the actual physical confrontation. The fourth stage was the conclusion of the confrontation. ${ }^{36}$ The final stage of the sequence of events was described as post-incident aftermath including psychological and behavioral adjustments. This analysis once again illustrates the importance of situational factors. ${ }^{37}$

Although the study did not specifically focus on gun-use events, many of the events described involved the use of weapons. Older respondents (men in their thirties to forties), explained that weapons had changed the dynamics of interpersonal violence. Fighting on the street was characterized as being unfair because of the power of guns, and carrying a weapon resulted from a lack of closure in an on-going interpersonal conflict. The study concluded that respondents packed a weapon because they anticipated violence or retaliation in the future and/or they knew from previous transactions that the antagonist had a weapon. ${ }^{38}$

Equally important in the study of situated transactions are the techniques of avoidance and dispute diffusion. Previous studies have looked exclusively at completed actions that resulted in some sort of criminal justice involvement. ${ }^{39}$ Other examinations have been similarly one-sided and may have distorted our understanding of situated transactions more generally. Little is known about events that do not end in physical fights or the firing of a weapon. ${ }^{40}$

34. OLIVER, supra note 7 , at 3-4, 43-47.

35. Id. at 153 .

36. Id. at 138. The conclusion included three types of endings: symbolic; overt; and internal. Id.

37. Id. at $139-40,151-52$.

38. Id. at $130-32$.

39. See, e.g., Luckenbill, supra note 7, at 176-77; Criminal Homicide as a Situated Transaction, 25 Social Problems 176-77 (1977); David F. Luckenbill, Patterns of Force in Robbery, 1 DeVIANT BEHAVIOR 361-378 (1980); Felson \& Steadman, supra note 7, at 61.

40. We are currently gathering information on diffused and "squashed" events to better understand the realm of possible scripts existing in the world of active gun users. See Fagan \& Wilkinson, supra 


\section{The Code of the Streets}

Firearm violence represents an extreme on a continuum of violence in the dynamics of inner-city youths. "Fair fights" have always been the most elementary form of interpersonal violence among inner-city youths, and perceived insults or transgressions typically have been grounds for fighting. ${ }^{41}$ Until the 1960 s, fatalities were rare, whether by firearm or any other weapon, and the circumstances that called for fighting generally were confined to territorial disputes, ritual displays of toughness, or family and ethnic solidarity. Rising homicide rates among inner-city adolescents in recent years suggest sharp changes in this social and behavioral landscape.

Yet, few studies have examined the current social worlds of young inner-city males in depth ${ }^{42}$ Elijah Anderson's study of inner-city Philadelphia is perhaps the most detailed description of violence and inner-city life. ${ }^{43}$ According to Anderson, the causes of inner-city violence are both structurally and situationally determined. ${ }^{44}$ He proposes that there are two types of normative systems operating within the inner-city context: the "decent" (locked into middle class values) families and the "street" (opposed to mainstream society) families. ${ }^{45}$ $\mathrm{He}$ argues that while the majority of inner-city residents are of the "decent" orientation, the street orientation has come to govern the normative system regarding human behavior in public spaces, especially among the young. Thus community norms on the street are regulated and enforced by the smaller minority who possess the street orientation.

The street code has a strong influence over the behaviors of young children, adolescents, and young adults. Accordingly, children growing up in this environment learn the "code of the streets" by navigating their way through interpersonal situations that often involve violent encounters. The street code provides rules for how individuals are to communicate with one another, how respect is to be earned, how and when respect is to be granted, and what should

note 9.

41. See, e.g., Elijah Anderson, A Place on the Corner (1978); Richard A. Cloward \& LLOYD E. OHLIN, DELINQUENCY AND OPPORTUNITY: A THEORY OF DELINQUENT GANGS 3, 14, 178 (1960); JAMES F. SHORT \& FREDERICK L. STRODTBECK, GROUP PROCESS AND GANG DELINQUENCY 251-54 (1965); GERALD D. SUTTLES, THE SOCIAL ORDER OF THE SLUM: ETHNICITY AND TERRITORY IN THE INNER CITY 323-52 (1968); FREDERICK M. THRASHER, THE GANG: A STUDY OF 1,313 GANGS in CHICAGo (1927); William F. WHYTE, STREET CORNER SOCIETY: THE SOCIAL SUbCULTURE OF AN ITALIAN Slum 5-6 (1981); James D. VIGIL, BARRIO GANGS: STREET LIFE AND IDENTITY IN SOUTHER CALIFORNIA 129 (1988).

42. But, see Anderson, The Code of the Streets, supra note 5; CANADA, supra note 5; MERCER L. SUllivan, "GeTting PAID": YOUTH CRIME AND WORK IN THE INNER CITY 1-18 (1989); Fagan \& Wilkinson, supra note 9.

43. Anderson, The Code of the Streets, supra note 5, at 80-94.

44. Id. at 81 . "The inclination to violence springs from the circumstances of life among the ghetto poor-the lack of jobs that pay a living wage, the stigma of race, the fallout from rampant drug use and drug trafficking, and the resulting alienation and lack of hope for the future." Id.

45. Id. at 83 . 
happen when someone disrespects or "disses" you. ${ }^{46}$ Violence and other types of domination are tools in promoting one's self-image, in other words, conquering others is one way of achieving higher levels of status. ${ }^{47}$

Anderson is mostly silent on the issue of lethal violence by firearms. Although he states that possessing a willingness to "pull the trigger" is an important part of an individual's quest for respect, he does not analyze the implications of gun use in the code of the streets. ${ }^{48}$ The availability of guns in the inner-city has undoubtedly raised the stakes even higher. It seems that "nerve," "toughness," and being a "punk" would take on new meanings within a climate regulated by lethally armed actors. This increased availability of guns in our inner-cities and the corresponding problems they pose have the subject of concern beginning in the late eighties. ${ }^{49}$

\section{E. Violence as Scripted Behavior}

Script theory offers a way of generalizing, organizing, and systematizing knowledge about the processual aspects and requirements of crime commission. The theory borrows heavily from cognitive psychology and was first articulated by Robert Abelson in $1976 .{ }^{50}$ According to Abelson, a script is a cognitive structure or framework that, when activated, organizes a person's understanding of typical situations, allowing the person to have expectations and to make conclusions about the potential result of a set of events. ${ }^{51}$ He explains:

The script concept raises and sketchily addresses a number of fundamental psychological issues: within cognitive psychology, the nature of knowledge structures for representing ordinary experience; within social psychology, the way in which social reality is constructed and how constructions of reality translate into social behavior through action rules; in learning and developmental psychology, how and what knowledge structures are learned in the course of ordinary experience; in clinical psychology, how resonances between present situations and past schemata can preempt behavior maladaptively. ${ }^{52}$

The concept of "procedural scripts" was introduced in a recent theoretical paper on offender's decisionmaking processes. ${ }^{53}$ Studying crimes as scripts

46. Id. at 82 .

47. Id. at $88-89$.

48. Id. at 92 .

49. SULlivan, supra note 42 , at 112 . Sullivan reported that there were more guns on the streets and that they were more frequently in the hands of younger offenders. Id.

50. Robert P. Abelson, Script Processing in Attitude Formation and Decision-making, in Cognirion AND SOCIAL BEHA VIOR 33 (J.S. Carroll \& J. W. Payne eds., 1976).

51. Robert P. Abelson, Psychological Status of the Script Concept, 36 AM. PSYCHOL. 717 (1981).

52. Id. at 727.

53. Cornish, supra note 8, at 7-10. Cornish's conception of "scripts" and scripted behavior varies slightly from the type of script discussed by Tedeschi and Felson. TEDESCHI \& FELSON, supra note 22, at 181-83. Cornish's "script" focuses in detail on the step-by-step procedures of committing crime that are learned, stored in memory, and enacted when situational cues are present. Tedeschi and Felson's use of the concept of scripts is as a way of explaining behavior that is seemingly impulsive (nonrational) as habitual learned responses to situational cues, which involves a limited number of decisions over which script is most cost effective in a given situation. While different in emphasis, both usages should be explored in the future research in this area. Derek Cornish, The Procedural Analysis of Offending, 
provides another useful framework for understanding the decisionmaking process involved in gun-use events. ${ }^{54}$

Research on child and adolescent violence suggests several ways in which script theory can explain violent events: (1) scripts are ways of organizing knowledge and behavioral choices ${ }^{55}(2)$ individuals learn behavioral repertoires for different situations; ${ }^{56}$ (3) these repertoires are stored in memory as scripts and are elicited when cues are sensed in the environment ${ }^{57}$ (4) choice of scripts varies between individuals, and some individuals will have limited choices $;^{58}(5)$ individuals are more likely to repeat scripted behaviors when the previous experience was considered successful, ${ }^{.9}$ and (6) scripted behavior may become "automatic" without much thought or weighing of consequences. ${ }^{60}$

The application of script theory to adolescent gun events as "situated transactions" may provide a level of understanding to a complex process that is not well understood. Adolescents are likely to look to the streets for lessons on the rules of gun fighting, learn from experience in conflict situations, and practice moves they have observed others performing in handling disputes on the street. ${ }^{61}$ The processes of learning and diffusion of this sort of gun "knowledge" remain unstudied and unknown.

What is needed are studies that will analyze interactions that involve young males and firearms using an event-based approach. This approach does not deny the importance of the individual attributes that bring people to situations, such as "disputatiousness," but recognizes that once there, other processes shape the outcomes of these events. ${ }^{62}$ Events are analyzed as "situated transactions," including rules that develop within specific socio-cultural contexts, the situations and contexts where weapons are used, the motivations for carrying and using weapons, and the personality "sets" of groups where weapons are used. There are "rules" that govern how disputes are settled, when and where firearms are used or avoided, and the significance of firearms within a broader adolescent culture. We need to understand these processes in order to have any hope of

in 3 CRIME PREVENTION STUdies 151-196 (R.V. Clarke ed., 1994).

54. See Cornish, supra note 8; Cornish, supra note 53, at 151-96 ("The unfolding of a crime involves a variety of sequential dependencies within and between elements of the action: crimes are pushed along or impeded by situational contingencies-situated motives; opportunities in terms of settings; victims and targets; the presence of co-offenders; facilitators, such as guns and cars.").

55. Abelson, supra note 50, at 35-36.

56. RICHARD SCHANK \& ROBERT ABELSON, SCRIPTS, PLANS, GOALS AND UNDERSTANDING: AN INQUIRY INTO HUMAN KNOWLEDGE STRUCTURE 36-37 (1977); TEDESCHI \& FELSON, supra note 22, at 181; Abelson, supra note 51, at 717; Rowell L. Huesmann, An Information Processing Model for the Development of Aggression, 14 AGGRESSIVE BEHAV. 14-16 (1988).

57. TEDESCHI \& FELSON, VIOLENCE, supra note 22, at 182; Abelson, supra note 51, at 716-17, 719; Kenneth A. Dodge \& Nicki Crick, Social Information Processing Bases of Aggressive Behavior in Children, 16 PERSONALITY \& SOC. PSYCHOL. BULL. 8, 12-14 (1990); Huesmann, supra note 56, at 14-16.

58. Dodge \& Crick, supra note 57, at 14-15.

59. SCHANK \& ABELSON, supra note 56, at 55-64; TEDESCHI \& FELSON, supra note 22, at 181.

60. TEDESCHI \& FELSON, supra note 22, at 181; Abelson, supra note 51, at 717.

61. Anderson, supra note 5, at 86; CANADA, supra note 5, at 21, 35 .

62. Luckenbill \& Doyle, supra note 7, at 422-23. 
intervening in future potentially explosive situations. Thus, research must examine both the symbolic and instrumental meanings of firearms in the lives of young males. We are currently engaged in a qualitative study of this nature to reconstruct the stages and transactions within gun events among inner-city adolescent males. ${ }^{63}$ Preliminary findings of this study are presented below.

\section{III}

\section{Firearms AND Adolescent Violence: Historical PeRspectives}

The use of firearms by adolescents is part of several recurrent delinquency problems. First, delinquent groups and street gangs in the United States have been involved in struggles to dominate urban areas for well over two centuries. Luc Sante describes the sometimes deadly and oftentimes comical struggles between early street gangs of New York City to control territory and assert their authority. ${ }^{64}$ In the late eighteenth century, gangs such as the Fly Boys, the Smith's Vly gang, and the Bowery Boys were well known in the streets of New York City. As European immigration increased in the early nineteenth century, gangs such as the Kerryonians (from County Kerry in Ireland) and the Forty Thieves formed in the overcrowded slums of the Lower East Side. ${ }^{65}$ These gangs warred regularly over territory with weapons including stones, hobnail boots (good for kicking), and early versions of the blackjack. Guns were rarely mentioned until the era following the Draft Riots of 1863 , when gangs fought with every weapon then available including pistols, muskets, and (rarely) canons. ${ }^{66}$ As smaller and more portable guns were developed, they became an important part of the milieu of gangs and street groups over the ensuing decades. Guns played a strategic role in settling conflicts and asserting dominance in matters of honor, territory, and business.

Historians are quick to point out that many of the perceived social sources of violence and homicide in the post-modern United States were as common in the late nineteenth and early twentieth centuries as they are today: rapid urbanization, population mobility, ethnic tensions, abuse of intoxicants, class conflicts, and the spread of cheap handguns. ${ }^{67}$ Yet, for much of the nineteenth century, homicide rates were declining. ${ }^{68}$ With the advent of concealable handguns around 1850 , homicide rates rose slightly but not enough to offset a long downward trend that had begun early in the nineteenth century. ${ }^{69}$ These declines were part of a 150-year historical trend where violence reached its ebb

63. Fagan \& Wilkinson, supra note 9.

64. LuC SANTE, LOW LIFE: LuRES AND SNARES OF OLD NEW YORK 219 (1991).

65. Id.

66. Id. at 201.

67. Roger LANe, Violent DEATH in THE CITY: Suicide, ACCIDENT AND MuRder IN NineteEnTH-Century PHILADELPHIA 6-10 (1979); Roger Lane, On the Social Meaning of Homicide Trends in America, in VIOLENCE IN AMERICA, PART I, 55-79 (Ted R. Gurr ed., 1989).

68. Ted R. Gurr, Historical Trends in Violent Crime: A Critical Review of the Evidence, in 3 CRIME AND JUSTICE: AN ANNUAL REVIEW OF RESEARCH 324-27 (Michael Tonry \& Norval Morris eds., 1981).

69. Id. at 316 . 
as the twentieth century began. The urbanization and modernization of the coming century offered new economic opportunities to both immigrants and migrants to the cities from rural areas which in turn fostered social controls.

Firearms played a prominent role in the growth of organized crime groups, beginning in the 1920s. These groups employed teenagers and street gangs in a variety of support roles, from running numbers to serving as lookouts for illegal gambling operations or liquor distribution points. ${ }^{70}$ Bootlegging and gambling provided a career ladder for teenagers. Of seventy-two "important" bootleggers identified by law enforcement authorities in the 1920s, most were young men in the later teenage years or early twenties. ${ }^{71}$ Firearms were a prominent part of the security system used to protect liquor shipments, and documents from bootleggers and smugglers claim there was more danger from "rum pirates" than from other bootleggers or the police. However, despite the involvement of adolescents in street gangs and emerging organized crime groups, there is little evidence that this led to the use of guns by teenagers.

During this time, problems of youth crime were serious enough to prompt the creation of juvenile courts in nearly every state in the United States. ${ }^{72}$ However, the crimes that motivated these reforms rarely involved violence or weapons. ${ }^{73}$ Even in this era when youth gangs were increasingly a part of the urban landscape, there was little mention of adolescent use of firearms in homicides or robberies. ${ }^{74}$ Nationwide, Uniform Crime Report data reveals that homicides increased from the turn of the century into the early $1930 \mathrm{~s}$, and then declined from 1933 to the early 1960 s. $^{75}$ The majority of local studies on homicides confirmed this trend. Throughout this period, differentials in homicide death rates between African-Americans and whites were quite pronounced. ${ }^{76}$ Yet, none of these studies examined adolescent rates separately from adult rates. Their silence must indicate either no noticeable differences between adolescents and adults, or that the base rates among adolescents were so small that they were not worth mentioning.

Nor was there much discussion of firearms in studies of delinquency from the Chicago School beginning in the 1920s. For nearly forty years, violence

70. Mark H. Haller, Bootlegging: The Business and Politics of Violence, in VIOLENCE IN AMERICA, PART I, 146-62 (Ted R. Gurr ed., 1989).

71. Id. at 148 .

72. STEVEN SCHLOSSMAN, LOVE AND THE AMERICAN DELINQUENT: THE THEORY AND PRACTICE OF "PROGRESSIVE" JUVENILE JUSTICE, 1825-1920 (1977).

73. James Bourdouris, Trends in Homicide, Detroit, 1926-1968 (1970) (unpublished Ph.D. dissertation, Wayne State University) (on file with author).

74. See id. For example, the analysis by Bourdouris of homicides in Detroit from 1926-68 does not mention adolescents. The data provide a composite picture of homicides as the product of quarrels between family members, lovers, or two males. Murders during robberies were rare. Id.

75. See Margaret Zahn, Homicide in the Twentieth Century United States, in History AND CRIME: IMPLICATIONS FOR CRIMINAL JUSTICE POLICY 28-63 (James Inciardi \& Charles Faupel eds., 1980).

76. See, e.g., Marvin WolfGang \& Franco Ferracuti, The Subculture of Violence: TOWARD AN INTEGRATED THEORY IN CRIMINOLOGY 263-64 (1967). 
among youth gangs involved fighting. ${ }^{77}$ While both common and makeshift weapons were used strategically in gang fights, firearms were extremely rare. ${ }^{78}$ Throughout this era, fighting was integral to the group identification of gangs and a central part of group interaction. Behavioral norms developed around fighting, and fighting had several meanings in gang life. ${ }^{79}$

By the 1960s, discussions of firearms in the literature on youth violence were more frequent, but not central in the delinquency literature. Although guns were prevalent in "streetcorner life," there were distinct situations where they were used and there were rules governing their use. They had a symbolic meaning in addition to their instrumental value, and generally represented a threshold of commitment to street life. Guns were rarely used by adolescents outside these contexts. Several studies of streetcorner life casually mentioned the presence of firearms and their use in settling interpersonal disputes. ${ }^{80} \mathrm{R}$. Lincoln Keiser's portrait of the Vice Lords also showed that weapons were not central to gang life, but were used selectively and strategically in conflicts with other gangs and in gang "business." 81 Among both gangs and "near groups," guns were valued as defensive weapons but sometimes also for offensive purposes. $^{82}$

Guns often were carried for show, with little intention to use them. ${ }^{83}$ Guns were used for impression management-that is, to convey to others that someone with a gun "means business" and is a person to be taken seriously. In some groups, people carrying guns, or even threatening to use them, could be easily dissuaded from shooting if face-saving alternatives were presented ${ }^{84}$

Gun use also was confined to specific situations and contingencies. In one reported incident, an important figure in a leadership clique brandished a weapon to break up a fight among gang members and then shot three gang

77. See THRASHER, supra note 41; Jeffrey Fagan, The Social Organization of Drug Use and Drug Dealing Among Urban Gangs, 27 CRIMINOLOGY 633, 634 (1989); Jeffrey Fagan, Gangs, Drugs, \& Neighborhood Change, in GANGS IN AMERICA 39, 41, 44-45 (Ronald Huff ed., 2nd ed. 1996).

78. Through the important works of the 1950 s, firearms again were not mentioned as part of the everyday life of gang members or other delinquent youths. See ALBERT COHEN, DELINQUENT BOYS: ThE CUlture OF THE GANG (1955); ClOWARD \& OHLIN, supra note 41 , at 198 . While some youths no doubt had and used weapons, firearms had a limited role in the social processes of delinquency.

79. LEWIS YABLONSKY, THE VIOLENT GANG 175-83 (1962); Irving A. Spergel, Violent Gangs in Chicago: In Search of Social Policy, 58 SOC. SCl. REV. 199-225 (1984); Walter B. Miller, Violence By Youth Gangs and Youth Groups as a Crime Problem in Major American Cities, Address to the National Institute for Juvenile Justice and Delinquency Prevention (1975) (on file with author).

80. ANDERSON, A PLACE ON THE CORNER, supra note 41; ULF HANNERZ, SOULSIDE: INQUIRIES INTO GHETTO CULTURE AND COMMUNITY (1969); Elliot LIEBOW, TALlEY'S CORNER: A STUDY OF NEGRO STREETCORNER MEN (1967); SUTTLES, supra note 41, at 198-201.

81. R. LINCOLN KEISER, THE VICE LORDS: WARRIORS OF THE STREETS 29-30, 34-36 (1969).

82. Id. at $31-34$.

83. Walter Bernstein, The Cherubs are Rumbling, in GANG DELINQUENCY AND DELINQUENT SubCULTURES 36, 45 (James F. Short, Jr. ed., 1968) (describing life in a gang of about 35 ItalianAmerican teenagers in the Park Slope neighborhood of Brooklyn). In Bernstein's account, guns were carried by only a very few members of the Cherubs, and almost never used. Id. at $36,45,48$.

84. Id. at 37 
members when the incident unfolded in a way that challenged his authority. ${ }^{85}$ The decision to shoot has been characterized as a complex decision, reflecting elements of cognitive mediation of the risks and reward of alternative outcomes, which is a function of a utility-risk paradigm where choices are contingent on in situ evaluations of these risks and rewards. ${ }^{86}$ The actor was motivated by the threat to his leadership status. ${ }^{87}$ Guns were used as a last resort, primarily because of the risks of arrest; but the risks of not using the gun to his status in the gang and in the neighborhood were also quite high. ${ }^{88}$ Finally, though it appears that the threat of retaliatory gun use was not evident in this incident.

In that era, guns were a minor part of street scenes of delinquent youths, and usually only within the province of the "toughest" youths or the leadership of delinquent groups. Guns were more often shown than used, their use was contingent and episodic, and gun episodes primarily were defensive or status conferring. Motivations for carrying and using guns often revolved around status concerns, and only after alternate outcomes had narrowed were guns actually fired.

In contrast to the rare but serious discussions of guns in the gang literature in the 1960s, similar discussions of guns in the 1970s gang literature were more frequent and their influence on interpersonal violence was more widespread. The presence of guns had become an important influence on trends in violence in central cities. ${ }^{89}$ In addition to violence toward other gangs, gun violence was also used to redress grievances against businesses and resolve personal disputes over women or drugs. ${ }^{90}$

IV

\section{FIREARMS IN CONTEXT}

Several studies on specific contexts of violence (for example, gangs, drug markets, robberies) suggest that gun use is infrequent and contingent, part of a context of a "situated transaction." In fact, many of these studies are somewhat casual in reporting the presence of guns, merely noting that they are

85. See Fred L. Strodtbeck \& James F. Short, Jr., Aleatory Risks Versus Short-Run Hedonism in Explanation of Gang Action, in GANG DELINQUENCY AND DELINQUENT SUBCULTURES 277-78 (James F. Short, Jr. ed., 1968).

86. Id. at $279-82$.

87. Id. at 279 .

88. There was cultural value to the action, as well, that enhanced the leader's status. He did not carry the weapon. In that incident, it was passed to him. The expectation of using guns was fairly high for specific types of conflicts. Beyond gangs and near groups, the fear of guns and community support for their use reflected what Strodtbeck and Short described as the widespread fear of sudden violence and the inability of police to stop it. Id. at 283-84. Guns were status conferring, and a valuable asset in a context where disputes are common, where they tend to be settled by violence, and where demonstrations of "toughness" are appropriate.

89. JOAN MOORE, HOMEBOYS 40 (1978) (describing how behavior patterns were accelerated by each successive generation of klikas).

90. VIGIL, supra note 41 , at 130-36.

91. Luckenbill, supra note 7 , at $184-85$; Felson, supra note 6. 
common features of these scenes. ${ }^{92}$ One consequence is that the influence of guns has not been carefully examined.

For example, although gangs have always been a venue where weapons were prevalent, but the presence and types of weapons have changed the stakes and calculus of gang violence. One study reported that 40.8 percent of incidents of gang violence in San Diego in 1988 were drive-by shootings, up from 23.7 percent in $1981 .^{93}$ Although drive-bys were favored by gangs over twenty years ago, the increase in the use of manufactured guns has de-emphasized the importance of fist-fighting in resolving gang conflicts. ${ }^{94}$ If gangs are an important context of gun use, the growing number of gangs and gang youths may have increased market demand for guns. As gangs emerge in cities and new gangs form, and consequently more adolescents join gangs, the simple probability of a conflict between gangs and gang members grows. ${ }^{95}$ If guns proscribe the rules and nature of settling gang conflicts, the likelihood of disputes settled by guns increases, as does the frequency of conflict.

Although drug markets are another context where gun possession is common, the precise relationship between drugs and guns is uncertain. Homicides by and of young males continue to rise or remain stable even as drug markets contract. ${ }^{96}$ Many homicides seem to be unrelated or tangential to drugs, involving material goods or personal slights. ${ }^{97}$ While the increase in homicides may have at one time reflected the expansion of the drug market, homicides may now-nearly a decade after the emergence of crack markets-reflect the residual effects of those markets. That is, guns that entered street networks during the expansion of drug markets remained part of the street ecology even as the drug economy subsided. ${ }^{98}$

Firearm use in robbery is the paradigm instrumental violent crime in the American consciousness. Because of its unpredictability and the threat of serious harm, it is one of the most feared crimes. Especially among adolescents, robberies often are unplanned or hastily planned events, the result of the instantaneous confluence of motivation and opportunity. ${ }^{99}$ Guns provide a tactical advantage in robberies, even beyond the advantage first created by the selection of time and circumstances. The choice of "coercive lethal resources"

92. See, e.g., Luckenbill, supra note 7, at 184-85.

93. WiLliam SANDERS, GANGBANGS AND DRIVEBYS: GROUNDED CULTURE AND JUVENILE GANG VIOLENCE 67 (1994).

94. Miller, supra note 79.

95. Jeffrey Fagan, Drug Selling and Illicit Income in Distressed Neighborhoods: The Economic Lives of Street-level Drug users and Dealers, in DRUGS, CRIME AND SOCIAL IsOLATION: BARRIERS TO URBAN OPPORTUNITY 99-142 (George Peterson \& Adelle Harrell eds., 1992).

96. UNDERSTANDING AND PREVENTING VIOLENCE 188 (Albert J Reiss, Jr. \& Jeffrey A. Roth eds., 1993).

97. Fagan, Gangs, Drugs, \& Neighborhood Change, supra note 77, at 44.

98. ANSLEY HAMID, BEAMING UP 1-40 (1994).

99. Franklin E. Zimring \& James Zuehl, Victim Injury and Death in Urban Robbery: A Chicago Study, 15 J. LEGAL ISSUES 1-40 (1986). 
(weapon or no weapon) determines the offenders opening move and the subsequent patterns of behavior in the robbery event. ${ }^{100}$

In reality, the increased availability and lethal nature of firearms has resulted in offenders taking on "risky or harder" targets, anticipating little or no resistance when using a lethal weapon and relying upon threat of force, which may or may not be followed up by use of force. ${ }^{101}$ Offenders can do more with lethal weapons and be successful at it. ${ }^{102}$ In robberies, victims are more likely to be injured by unarmed (non-gun) offenders than by offenders with a gun. ${ }^{103}$ Victims are sufficiently intimidated by the weapon to comply more readily with the offender's demands. ${ }^{104}$ However, Philip Cook notes that the presence of a firearm does open the way for a robbery to become a homicide. ${ }^{105}$

While firearms may often be present during robberies, their use in the course of a robbery reflects other contingencies, such as "recreational violence." 106 There are predictable stages for the robbery event, and when responses fail to meet the robber's expectations, threatened violence may become actual to gain compliance or to get the event back on its planned course. $^{107}$ Difficulties are introduced in robbery situations when victims (or third parties) do not adhere to the robbery "script." At that point, the offender is faced with the decision to back up his lethal threats with action. This stage in the event may be complicated by the young offenders' limited reasoning ability. Adolescence is a developmental stage when abstract reasoning about the consequences of using guns and cognitive capacities to read social cues are incomplete. ${ }^{108}$ The choices in these situations may be seen as "black and white" or "all or nothing" for the adolescent robber. During the course of a robbery, the teenager armed with a gun (presumably inexperienced) becomes an unstable actor in a scenario whose outcomes are dependent on a predictable set of interactions between the robber and his victim. It is when the initial definition of the situation strays from robbery to a threat, personal slight, or conflict (in the wake of resistance) that seemingly irrational violence occurs. When guns are present, the violence often results in death.

100. Luckenbill, supra note 39 , at 367 (concluding that "based on the observations of the interviewed offenders, that offenders with lethal resources open the transformation process with a threat of force, whereas offenders with nonlethal resources open with incapacitating force").

101. Wesley Skogan, Weapon Use in Robbery, in VIOLENT CRIME: HISTORICAL AND CONTEMPORARY ISSUES 68 (James A. Inciardi \& Ann E. Pottieger eds., 1978).

102. Id.

103. Philip J. Cook, Reducing Injury and Death Rates in Robbery, 6 POLICY ANALYSIS 36-37 (1980).

104. Id. at 36.

105. Id. at 42.

106. Zimring \& Zuehl, supra note 99.

107. Skogan, supra note 101, at 64-65; Floyd Feeney, Robbers as Decision Makers, in THE REASONING CRIMINAL: RATIONAL CHOICE PERSPECTIVES ON OFFENDING 53, 66-71 (Ronald V. Clarke \& Derek B. Cornish eds., 1986).

108. Jerome Kagan, UnSTAble IdeAs: Temperament, Cognition, ANd Self 10-15 (1989). 
Once again, these studies illustrate the highly contextualized patterns of gun use by young males, and the importance of guns as part of the contingencies of violence in disputes. They suggest that guns are part of the ecology in inner cities, and have become a variable in event decisionmaking during disputes. The symbolic and instrumental meanings of violent behavior develop in a specific socio-cultural context, and we will expect that they will reflect the physical and social isolation that young people experience in inner-cities. This context may shape how young males develop a range of behavioral styles and evaluate the contingencies of behavioral choices. Advanced segregation ${ }^{109}$ and social isolation ${ }^{110}$ of inner-city communities create social boundaries that effectively seal off adolescent networks from potentially moderating influences of other social contexts. In these circumstances, cultural diffusion transmits such views and behavioral norms quite efficiently. ${ }^{111}$ High levels of exposure to violence, including witnessing or participating in the death of peers, friends, family members, or neighbors, has become a way of life for too many inner-city adolescents. Thus, these adolescents are exposed to a limited set of problemsolving techniques and when conflict or threatening situations occur, violence is often one of the few options available. Adolescents simply do what they know in these situations. The handling of one situation by using violence feeds into the next situation, and so on. The costs of violence to the offender, including death by gunfire, are rated very low in this context, especially compared to his criminal goals. ${ }^{112}$ Futures, especially for males, are seen as tenuous both in terms of survival into adulthood and any hope of being successful in life.

Lacking an attainable future, or at least the belief in one, and absent models of deferred gratification and conventional success, it is all too easy to see how life can quickly become a quest for the immediate gratification of present impulses, a momentto-moment existence where weighing the consequences of today's behavior against their future implications is largely pointless. ${ }^{113}$

Thus, what may appear as a problem of impulsive violence may in fact reflect a calculation of the benefits of restraint compared to the short term payoffs from high-risk acts of violence. ${ }^{114}$

109. DOUglas S. MASSEY \& NANCY A. DeNTON, AMERICAN APARTHEID: SEgREGATION AND THE MAKING OF THE UNDERCLASS 160-62 (1993).

110. Sampson \& Wilson, supra note 3, at 37-54.

111. See, e.g., Marta Tienda, Poor People and Poor Places: Deciphering Neighborhood Effects on Poverty Outcomes, in MACRO-MICRO LINKAGES IN SOCIOLOGY 244, $249-50$ (Joan Huber ed., 1991).

112. AleXANDER KotLowITZ, THERE ARE No CHILDREN HERE (1991); Anderson, The Code of the Streets, supra note 5, at 92.

113. JOSEPH SHELEY \& JAMES WRIGHT, IN THE LINE OF FIRE: YOUTH, GUNS, AND VIOLENCE IN URBAN AMERICA 160 (1995).

114. In this context driven by fear, young people believe that life is dangerous, that anything (fatal) can happen at any time, and that having a gun is a necessary, if not attractive, option. LH Research, supra note 1 , at ix. The more that guns are present within their social networks, the more they seem normative and the more inured kids become to the realities of guns. In a world where they see themselves as having no power or control over the dangers and fears they evoke, guns provide a means to reduce fear and regain some defense against ever-present threats and enemies. Some young males 


\section{$\mathrm{V}$}

\section{CHARACTERISTICS AND RISK FACTORS OF ADOLESCENT GUN VIOLENCE}

Most of what we know about young people and guns comes either from newspaper and magazine features or a very small number of student surveys. The surveys typically measure student attitudes, behaviors, and opinions about guns in the school environment, and attempt to locate characteristics and attitudes of youths who carry or use firearms.

\section{A. The LH Survey}

The most recent survey, by LH Research, questioned 2,508 adolescents in ninety-six randomly selected elementary, middle, and senior high schools. ${ }^{115}$ The results showed that handguns were a significant part of their everyday social ecology. About one in seven (fifteen percent) reported carrying a handgun in the past thirty days, and four percent reported taking a handgun to school during the year. ${ }^{116}$ Nine percent of the students reported shooting a gun at someone else, while eleven percent had been shot at during the past year. ${ }^{17}$ Thirty-nine percent of the youths reported that they personally knew someone who had been either killed or injured from gun fire. ${ }^{118}$ Twenty-two percent reported that carrying a handgun would make them feel safer if they were going to be in a physical fight. ${ }^{119}$ More than fifty percent (fifty-nine percent) could get a handgun if they so desired. ${ }^{120}$

The presence of guns also affected the students' emotional well being, including fear and shortened life expectancies. For example, forty-two percent said they worry about "being wiped out from guns" before reaching adulthood. ${ }^{121}$ Not surprisingly, those who worry most and those who carry guns often are the same individuals. Guns also affected the routine activities of both gun-carrying and gun-avoiding students: forty percent reported behavioral changes to cope with violence including decisions on where they go, where they

may decide that the option of defense through gun use is too attractive to pass up, especially when weighed against the social and mortality costs of not carrying it. Id.

115. Id. at iii. The survey was a simple random sample of classrooms in public, private, nonCatholic, and Catholic schools. The self-administered anonymous questionnaires included questions on gun ownership, carrying firearms, using guns, injury, and perceptions of safety. The sample was divided among central city schools $(30 \%)$, suburban schools $(46 \%)$, and schools in small towns or rural communities $(24 \%)$. The recipients of the survey were predominantly caucasian $(70 \%)$, with a significant number of African-American students (16\%), Latino students $(15 \%)$, and Asian or Native American students (4\%). Most students (87\%) attended public schools, with small samples from private non-Catholic schools (8\%), and attended Catholic schools (5\%). Id. at iv.

116. Id. at vi.

117. Id.

118. Id.

119. Id. Id.

120. Id. Of those who knew where to get a firearm, two-thirds could obtain one within 24 hours.

121. Id. 
stop on the street, night time activities, what neighborhoods they walk in, and what friends they choose. ${ }^{122}$

There are several important limitations of the study, however, and in the end it fails to address the disproportionate rates of gun fatalities among AfricanAmerican youths. The school-based sample under-represents young AfricanAmerican males who are at the highest risk of mortality from guns and have the highest concentration of risk factors. ${ }^{123}$ Dropouts, frequent absentees, and institutionalized youths are also excluded, a source of bias since these groups have higher rates of both violence and the risk factors for violence. ${ }^{124}$ The analyses of gun possession and carrying by subgroups (area, gender, or ethnicity) was limited and selective, and the general population sample would likely yield cells too small for reliable comparisons when such controls are introduced. Nevertheless, the LH study suggests the pervasive influence of guns on the everyday decisions of young people in schools.

\section{B. The Sheley, Wright, and Smith Survey}

Some of the limitations in the LH survey were later addressed by others, including research by Joseph Sheley and by Sheley and James Wright. ${ }^{125}$ They interviewed 835 male inmates in three juvenile correctional institutions in four states, complemented by surveys of 758 male high school students from ten inner-city public schools in the largest cities in each state. ${ }^{126}$ Both student and inmate samples were voluntary, and non-incarcerated dropouts were not included. Most (eighty-four percent) of the inmate sample reported that they had been threatened with a gun or shot at, and eighty-three percent owned a gun prior to incarceration. ${ }^{127}$ More than one in three inmates (thirty-eight percent) reported shooting a gun at someone. ${ }^{128}$ More than half owned three or more guns, and the age of first acquisition was fourteen. ${ }^{129}$

Both the inmate and student samples described in more detail the ecology of guns within the social organization of their neighborhoods. They claimed that firearms were widely available at low costs. ${ }^{130}$ Distribution was informal, with guns bought and sold through family, friends, and street sources. ${ }^{131}$ Among incarcerated young males, forty-five percent reported that they "had bought, sold, or traded 'lots' of guns." ${ }^{132}$ Stealing guns and using surrogate buyers in gun shops were common methods of obtaining guns. Motivation for

122. Id. at ix.

123. Fagan et al., supra note 2 at 439, 447-48.

124. Id.

125. SHELEY ET AL., supra note 1, at 2-3; SHELEY \& WRIGHT, supra note 113, at xi-xii, 15.

126. SHELEY ET AL., supra note 1 , at 1.

127. Id. at 4.

128. Id.

129. Id. at 5 .

130. Id at 5-6.

131. Id at 6 .

132. Id. at 7-8. 
owning and carrying guns was reported to be more for self-protection than for status. The drug business was a critical context for gun possession: eighty-nine percent of inmate drug dealers and seventy-five percent of student dealers had carried guns. ${ }^{133}$ So too was gang membership: sixty-eight percent of inmates and twenty-two percent of students were affiliated with a gang or quasi-gang, and seventy-two percent of inmates were involved in the instrumental use of guns. ${ }^{134}$

Although one of the studies focused on inner cities, the voluntary samples raise concerns regarding selection bias and other measurement error. The Sheley and Wright study sampled disproportionately from states and cities with concentrations of gang activity, ${ }^{135}$ perhaps overstating the importance of gangs as a context for gun use. Like the LH survey, this study did not focus on events where guns were used, only on individuals and their patterns of gun possession and gun use.

\section{Other Adolescent Studies}

Other studies have examined the prevalence of gun or weapon possession, but with little specificity. One group interviewed 611 youths in inner-city neighborhoods in Miami as part of a study on crack cocaine and "street crime." 136 They reported that 295 (forty-eight percent) carried guns in the year preceding the interview. ${ }^{137}$ However, they do not report the percentage that used them or in what contexts they had been carried (drug deals, robbery, or homicide). The National Youth Survey is generally silent on the question of weapons. ${ }^{138}$ Based on 1,203 student surveys and interviews with dropouts in three cities with high gang concentrations, Jeffrey Fagan reported that 42.5 percent of gang males and 17.6 percent of non-gang males carried weapons. ${ }^{139}$ But his findings made no distinction between guns and other weapons (for example, knives). Also, Allan Lizotte and others examined the role of peers, social networks, and lifestyles on the carrying and use of firearms, using data from the Rochester Youth Survey. ${ }^{140}$ They found that individuals who possessed firearms for the purpose of "sport" were socialized into gun use primarily within the family while youth who possessed guns for "self-protection" purposes were socialized into gun use within their peer networks. ${ }^{141}$

133. Id. at 8 .

134. Id. at 9 .

135. SHELEY \& WRIGHT, supra note 113 , at xi, 15.

136. JAMES A. INCIARDI ET AL., STREET KIDS, STREET DRUGS, STREET CRIME: AN EXAMINATION OF DRUG USE AND SERIOUS DELINQUENCY IN MIAMI 162 (1993).

137. Id.

138. See, e.g., ElLIOTT ET AL., supra note 3, at 1-2.

139. Jeffrey Fagan, Social Processes of Delinquency and Drug Use Among Urban Gangs, in GANGS IN AMERICA 183-219 (C. Ronald Huff ed., 1990).

140. Allan J. Lizotte et al., Patterns of Adolescent Firearms Ownership and Use, 11 JUST. Q. 51, 61-62 (1994).

141. Id. 
These studies are not very helpful in explaining the use of firearms by young males or the procedural dynamics of such events. They typically confound firearm use with firearm possession, and also with other forms of adolescent violence (such as physical and sexual assault, robbery) or poor developmental outcomes such as drug use, dropout, or adolescent pregnancy. ${ }^{142}$ Few studies have distinguished adolescents who are violent from those violent adolescents who carry or use firearms. They often fail to distinguish firearms from other weapons, despite important strategic differences. There also is little information on nonlethal firearm use, virtually no information from gunshot victims, and little research on the situations and contexts in which adolescents carry or use guns. ${ }^{143}$

\section{Gender, Firearms and Youth Violence}

Our research focuses upon male firearm use because the growing presence of firearms has had minimal influence on female adolescents. Historically, female offenders have not used weapons, but they may carry weapons for males. ${ }^{144}$ Homicide data also show the rare involvement of both gang and non-gang females in lethal violence. ${ }^{145}$ Bjerregaard and Lizotte omitted girls from their analysis of gun ownership among inner-city youths because "girls rarely own guns, whether for sport or protection."146

Survey data also indicate low rates of gun or other weapon use by female adolescents. The rate of female high school students who carried a firearm to school was reported to be about one percent. ${ }^{147}$ And, though Sheley and Wright state that nine percent of the female respondents reporting having owned a revolver at some time in their lives, five percent had owned an automatic or semiautomatic weapon, and fewer than five percent owned other

142. E.g. ELLIOTT ET AL., supra note 3, at 5-86.

143. Only homicide research has examined the contexts surrounding firearm use, but most of these studies have focused on specific contexts such as spousal violence, gangs, or drug exchanges. See, e.g., Paul J. Goldstein et al., Crack and Homicide in New York City, 1989: A Conceptually-Based Event Analysis, 16 CONTEMP. DRUG PROBS. 651-687 (1989); Cheryl L. Maxson et al., Differences Between Gang and Nongang Homicides, 23 CRIMINOLOGY 209, 216-218 (1985).

144. VIGIL, supra note 41, at 98-103; JOAN MOORE, supra note 89; JOHN QUICKER, HOMEGIRLS: CharacterizING CHICANA GANGS (1983); BETTY-Lou VAlENTINE, HuSTlING AND OTHER HARD WORK: LIFE STYLES IN THE GHETTO (1978).

145. Cheryl L. Maxson \& Malcolm W. Klein, Street Gang Violence, in Pathways to CRIMINAL VIOLENCE (Marvin E. Wolfgang \& Neil A. Weiner eds., 1989); IRVING A. SPERGEL, THE YOUTH GANG PROBLEM: A COMMUNITY APPROACH 58 (1995) (reporting that only one of 345 gang homicide offenders in Chicago between 1978 and 1981 was female; only six of 204 gang homicide victims were female). Between 1988 and 1990, two of 286 gang homicide offenders were females; three of 233 gang homicide victims in this period were females. Spergel concludes that "the youth gang problem in its violent character is essentially a male problem." Id.

146. B. Bjerregaard and Alan Lizotte, Gun Ownership and Gang Membership, 86 J. CRIM. L. \& CRIMINOLOGY 43 (1995).

147. L. Sadowski et al., Firearm Ownership Among Nonurban Adolescents, 1434 AMERICAN JOURNAL OF DISEASE OF CHILDREN 1410-13 (1989); C.M. Callahan \& F.P. Rivera, Urban High School Youth and Handguns, 267 JAMA 3039-3042 (1992). 
types of firearms, ${ }^{148}$ fewer than three percent carried weapons to school, and only eight percent carried them outside the home. ${ }^{149}$

Our current research attempts to reconstruct the stages and transactions within gun events among inner-city adolescent males. ${ }^{150}$ Lengthy interviews with young men who have been involved in gun violence are generating data on the dynamic exchanges within gun events, including those where violence ensued and others where violence was avoided. The young men are asked to reconstruct three violent events: one where guns were present and they were used; one where guns were present but they were not used; and one where guns were not present. The sample consists of young men (aged sixteen to twentyfour) who were released from Rikers Island Academy between April 1995 and May 1996, and who entered a membership program called Friends of Island Academy, Guys' Insight on Imprisonment for Teenagers ("G.I.I.F.T."). ${ }^{151}$ The analysis of the interview narratives will focus on the presence of "scripts," the various forms and types of scripts that are employed in specific contexts, how they are employed in different circumstances or contexts, and the roles of contexts and circumstances in shaping the outcomes of violent events.

Several caveats should be considered. The data presented here are drawn from thirty of eighty cases. These analyses, while computer aided, are very preliminary. While we suspect that further analysis will be consistent with these preliminary findings, additional themes will emerge and patterns will become more salient as the sample size increases. The themes and patterns identified in this paper, and therefore the quotations used, represent consistency across at least five cases. ${ }^{152}$ Although our findings are consistent with other recent studies, the level of insight gained through these detailed qualitative narratives on adolescent gun use goes beyond previous studies.

\section{VI}

\section{The Symbolic and InStRUmental MEANings of FiREaRmS}

Today, there seems to be an increase in the number of situations and contexts in which conflicts arise that may escalate to lethal violence. The use of violence may reflect an apparent lowering of the thresholds for using

148. SHELEY \& WRIGHT, supra note 113 , at 123.

149. Id.

150. This research is supported by grants from the Centers for Disease Control and Prevention, the National Institute of Justice, and the National Science Foundation. Developmental and pilot research was supported by the Harry Frank Guggenheim Foundation.

151. For a detailed discussion of the methodology for this study, see Deanna L. Wilkinson et al., Using Peer Interviewers to Enhance Data Collection Efforts in a Study of Gun Use Among Young Males in the Inner City: Tales from the Field, presented at the Academy of Criminal Justice Sciences Annual Meeting (Mar. 15, 1996) (on file with author).

152. We decided that patterns that heid up across five different individuals in this data set could be considered strong enough for consideration and discussion. As noted in the text, many of the themes were found across nearly all of the subjects, however, there were also many other apparent themes that failed to meet the five-case minimum cut-off point. 
weapons to resolve conflicts. Individuals can have a variety of different experiences with guns, including owning, carrying, buying, selling, trading, stealing, having access to, borrowing, threatening someone with a gun, beating someone with a gun, firing for play, firing to injure, and firing to kill. It appears that gun use has become a central part of status and identity formation within the "street-oriented" world of the inner-city. Guns have both symbolic and instrumental meanings within this context. Below we discuss some of the recurrent themes emerging from our data on adolescent gun use events in the inner city.

\section{A. The Role of Guns in Identity Formation and Status Attainment}

Social identity is extremely important within inner-city neighborhoods. As described above, impression management, reputation, and image are necessary for daily survival. ${ }^{153}$ Our preliminary analysis suggests that gun violence is the ultimate tool in forming and sustaining positive social identities within the neighborhood. One subject explained:

Interviewer D: So umm, why is it important to have a reputation? G-58: . $^{\text {s4 }}$ "Cause if you ain't got no rep ...; it's gonna be like this if you ain't got no rep, everybody is gonna pick on you ... ; they gonna be like oh that nigga pussy, he don't do nothing, they gonna try to pick you as a herb, you coming up the block niggas be trying to bump you, look at you, ice grill you look at you up and down . . like you nobody. D: Yeah. G-58: So that when you gotta go all out, man, you know? D: What you mean by "go all out"? G-58: You gotta go all out, you go "lace" 'em . . .; have a fight with duke or whatever, pull out a gun and blast 'em ...; you gotta be, niggas ain't gonna fuck with you if you shoot a nigga . . . ; just lace "em, and niggas will say "yo that nigga don't play, he lace something in a heartbeat."

Projecting the "right image" may have consequences for personal safety, social acceptance, and self-esteem among individuals.

Interviewer R: What about image or a reputation on the streets? G-61: Image? Well, a image is something, is a very, it's important on the streets . . ; we just show how we come out and show themselves as somebody they not, then people, some people could look and see a fake person between a real person. A real person is the person that ... I see is that don't take no shit, just do anything that he wanna do or whatever or he gets down for whatever .... A fake nigga is a nigga who talk about it but when its time to get down, he got excuses, he got to do this or come up with an excuse or all he do is politic about, talk about. They never really get in the mix . . ., he just talk about it. [I]t's just, you know, you gotta, you just like, you look at you people as your son, daughter, you got to look out for them, and they gotta do the same for you .... That comes with my other thing, 'cause you gotta, if you gotta problem I'm there and if I got a problem you there ...; and another thing when, in the streets police is mostly hated,... they are least involved with anything, ... they got, they familiar what's goes on, but people do not want them involved with them. R: Why? G-61: I don't know. They feel more safer without the police than with the police.

153. See Anderson, The Order of the Streets, supra note 5, at 80, 82, 86-89; CANADA, supra note 5, at 38-39. But, see, SHELLEY \& WRIGHT, supra note 113, at 64-65 (surveyed sample rejected statement that gun ownership was important for image and respect).

154. The G-58 or any other number following the " $G$ " refer to the interviewee being quoted. 
Thus, building a reputation is something that young males take seriously and into which they put effort. A reputation can be won via several routes, which are all connected by the threat or use of violent force. One subject explained how it works:

Interviewer $\mathrm{R}$ : How you get a rep, you know? You know how some brothers, sometimes brothers just go out there looking to get a rep. Be the man. G-42: Those are called like new comers . . . ? Like a person that moves into a new community he's like, he's like damn you know "nigga's out here is cool and they real I got to show these niggas I ain't no punk yo." So when he hangs out with them, he see any of them about to get into a "scrobble" he be like "yo step back money I'll handle this for you yo" ... he's only doing it for a rep cause it's not like that's your brother and you like "Nah, yo you ain't going to fight my brother. For that you fight me." R: Nigga's is just doing it to get a name? G-42: Doing so people could look at him and be like "oh word that nigga bust that nigga's ass yo word." I don't know that's the way I look at it.

Social interaction is regulated through a strict adherence to a proscribed dominance hierarchy where there are only a limited number of desirable statuses to attain. Displays of respect are expected by those who have higher levels of status on the street. However, shows of disrespect or "dissing" is often an intended or unintended attack on someone else's identity and, according to the "code of the street," be addressed aggressively.

G-61: Getting dissed? Interviewer R: Is that deep or what? G-61: That's deep, according to the street that's really deep, 'cause if a nigga diss you, he feel you dissed everything, he just ran over you like a mop, just walked over you like a mat. If somebody disrespect you everybody will, that's why there be a lot of killing in the neighborhoods today, niggas ain't trying to get disrespected. R: But why do words have to end in death? G-61: Just, it's not like it used to be, most of the time some people just talk it out, or fight it out. R: Yeah. G-61: But now since there are so much guns, people ask "why should I scuffle my knuckles out or bruise up my face when I can use some that will take care of the problem in less than five minutes?" Most people just say fuck fighting. R: That's taking a life, man. G-61: Most people don't look at it like that; they be like "that's one less problem in life I got to worry about."

Subjects often talked about verbal attacks on one's mother and how that type of attack could not be tolerated. As one subject described:

Interviewer M: Why you fired, what was the situation? G-56: Well somebody played themself in trying, try to disrespect my moms, so I had to handle my business. May he rest in peace black.

Doing time (in jail or prison) and having a lot of guns were described by several young men as being important ways to attain status.

Interviewer W: Can you describe the importance of image and reputation on the street? What is reputation mean? G-33: Reputation? W: Have rep.? G-33: Nowadays is, some people look at it as a because they got locked up, they come home you know, he got a rep, and like that, you know. "Oh, that's the man right there, he did a 5 bid or he did a 10 bid." And the truth is nigga was ass in there. People look at it like that. W: Is it the same for all guys? G-33: No, you know for some who chillin' in the better rhine. Who got the more guns. You know, whatever. Stupid things. Like me I don't care if I . . . To some people it is. To me it's got no importance, it holds no weight. 
As shown above, violence is a central tool in gaining or losing respect. Having a strong reputation can protect young men from attacks or robberies by others.

G-44: Yeah. You make money, if you make money it's just gonna come. Interviewer R: If you make money then you get your props? G-44: You'll get your respect then everybody gonna want to be down with you instead of robbing ... instead of robbing you, everybody think "yo why should I rob him" you know what I'm saying he show if he could show me something, he could show me how to make mine. R: True. G-44: They, while they robbing him they going home getting a certain amount of money, but he making more, he making the money that he lost. And everybody want that everybody want to make the money that they lost and not stress. I'm saying "he stole like five G's from us already. Don't stress it I'm making more money, I'm make it again next week."

Within the context of status and identity posturing, ordinary conflicts that occur over personal slights, looks, insults, or playful threats may turn to murder in a matter of minutes.

Interviewer R: Did you ever shoot anyone? G-61: Yeah. R: When? Before you got shot or after? G-61: After, after I got shot. I shot somebody, we had this conflict, this kid, I don't know him but we was just sitting next, and he exchanged words with my friend, so he told, he came to the kid, the kid came to my friend and told him to move ... ; so my man was like "move, what you mean move, man, the word is excuse me," he was like "no move," . . some rude boy. So he was like, I heard them, so I turned around and said, "yo what the fuck is going on, yo," the kid talking about "what you gonna do," so I said "what you mean what I'm gonna do," so I shot 'em . . . R R Where you shoot 'em? G-61: I don't know where I shot 'em at, I shot 'em up in the face. R: What you just shot 'em and left. So umm, you left? G-61: Yeah. R: So what happened you ain't hear what happened? G-61: I heard he was dead. R: Oh, so umm, how that made you feel? G-61: Fine. But then again it made me feel like, after that I felt like I was still on my mission, I was like fuck that. He ain't mean nothing to me ...; he wasn't nobody to me so, he ain't mean nothing to me . . . R: Did you feel like your life was threatened like? G-61: I ask myself that question all the time, I be saying to myself "damn, did I make the right decision? Was that the right decision or not. ..." And I haven't come up with an answer yet.

\section{B. Toughness}

"Toughness" has been central to adolescent, masculine identity in American life. Physical prowess, emotional attachment, and the willingness to resort to violence to resolve interpersonal conflicts are hallmarks of adolescent masculinity. ${ }^{155}$ While these terms have been invoked recently to explain high rates of interpersonal violence among nonwhites in central cities, "toughness" has always been highly regarded and a source of considerable status among adolescents in a wide range of adolescent subcultures, from streetcorner groups to gangs. ${ }^{156}$ In some cases, displays of toughness are aesthetic: Facial expression, symbols and clothing, physical posture and gestures, car styles, graffiti, and unique speech are all part of "street style" that may or may not be complemented by 40.

155. Elijah Anderson, The Code of the Streets, supra note 5, at 80, 89-92; CANADA, supra note 5, at

156. CANADA, supra note 5, at 21-22; GOFFMAN, supra note 16, at 83-84; Whyte, supra note 41 , at 4; WOLFGANG \& FERRACUTI, supra note 76, at 305; William Oliver, Black Males and the Tough Image: A Dysfunctional Adaptation, 8 W. J. BLACK STUD. 199, 200-01 (1984). 
physical aggression. While changing over time with tastes, these efforts at "impression management" to convey a "deviant aesthetic" and "alien sensibility" have been evident across ethnicities and cultures. ${ }^{157}$ Toughness requires young males to move beyond symbolic representation to physical violence. ${ }^{158}$ Firearms often are used to perpetuate and refine the aesthetic of "toughness," and to claim the identity of being among the toughest.

In our data, "toughness" and "being the man" were two strong concepts for all subjects and most of the violent events they described. Again, our data show that guns are an important part of these social processes. Guns are equated with status and with a certain level of respect.

Interviewer M: What makes somebody tough or a big man in your neighborhood? G-56: What make 'em tough? M: Yeah. G-56: When they got guns. When they got when they got a whole lot of friends know the guys back. Of course he gon say he the big man, nobody could touch him. He got prop, he got juice.

Another subject explained that violent behavior and guns are important for defining manhood for young pre-teens and adolescent males.

Interviewer R: How is manhood defined? G-40: Manhood now it's like gunhood. If you got a gun you the man (laughing). Ain't no more manhood it's gunhood.

\section{Power and Dominance}

Power and dominance were also salient themes in our preliminary data. Previous research suggests that "bad asses," robbers and other fighters, seem to gain much pleasure from violence, including the use of guns and other weapons. ${ }^{159}$ There are several possible explanations, from the feelings of power and security that weapons may provide, to the pleasures of dominance and unrestrained "ultimate" aggression that guns provide. One subject describes why he got a gun and how it made him feel to have it.

Interviewer D: When did you get your first gun you know? At what age? G-51: What age. I got my first gun at age of I think was sixteen. D: Why why'd you get it? G-51: 'Cause I wanted to be bad. D: You wanted to be bad huh? G-51: I wanted to be like I had a reputation to keep so maybe with a gun would have boost it up a little bit more. D: Have you ever fired a gun ?... G-51: Yes. D: How'd it feel firing a gun, how'd it ... ? G-51: It felt, it felt good.

The use of weapons may reflect a total identity that is geared to dominate if not humiliate adversaries. Some adversaries are created in order to express this dominance. Another subject reported how his identity as being "trigger happy" gave him status and also brought him into many additional conflicts.

G-61: Yeah it might turn out tragic .... Interviewer R: So when you shot the guy you shot, when you shot him, or when you found out he was dead or something, how did that make you feel, did that give you, did that boost you up? G-61: It ain't hype me;

157. KATZ, supra note 6 , at 88-89.

158. This does not suggest merely any physical action. It also requires a display of pleasure beyond the instrumental purposes of the act, and well beyond whatever calculation followed an initial dispute. Thus, domination, and its payoffs in pleasure as well as status, supplant the instrumental goals of physical violence.

159. See KATZ, supra note 6, at 80-113, 193-236. 
it didn't make me feel like going out there and doing it again; it just made me feel like ... I just gotta stripe; that's how that made me feel, I got a stripe. R: Did you get a reputation after that? G-61: Well, I kept a reputation but, ... 'cause I was into a lot of stuff, ... and thing I did came to where I was like one of the people, I was like one of the most people they would come and get when it was time for conflict, then anybody ... that I really be around, when there beef, when it's beef time they know who to come get and outta those people, I was one of the top ones they would come and get ... 'cause they always known me ... for being trigger happy and ....

While this from of violence has a long history, its recent manifestation as "senseless" violence may in fact simply reflect the changes brought about by the availability of weapons and the meanings ("scripts") attached to them. The perpetuation of the sense of self and the image in the minds of others also is an instrumental goal of much weapon use. There is a very low threshold for the use of violence for these ends. Some subcultures or networks may also reflect norms where excessive violence, including weapons use, is valued, gains social rewards, and gives great personal pleasure. For example, this is true in some gang contexts where "locura" acts of violence establish one's status in the gang. It is senseless only in the fact that the violence is an end unto itself. The use of weapons, especially guns, has elevated the level of domination. Guns can be used tactically to disable an opponent, or to humiliate an opponent by evoking fear (begging, tears, soiling his pants, etc.), even if there is little advantage gained by using the weapon.

Adolescent gathering locations are "hot spots" of violence where weapons are part of the scenario of fighting. What characterizes these locations is a combination of individual personality "sets," their expectancies about what might happen in that locale (at what time of the day), and the absence of social controls (restraints) in those spaces. These places are flashpoints for conflict, posturing, imaging, and impression management. Carrying weapons is an expressive part of this world. Carrying a gun also may alter an individual's perception of safety within different locations. As one subject explained, with a gun "you could go places you wouldn't go."

Interviewer $\mathrm{R}$ : Through selling drugs I know you had to maybe like experience guns? G-42: Yeah. I had my experience with guns but I never and I thank god I never had to shot nobody but I pulled out on somebody before, I slap somebody with a gun before. R: Why is that? Tell me about those times? G-42: Alright umm. One time boom I was kind of young too I was like fifteen. My cousin had a lot of guns I asked him to let me hold it and I just held it and at that time. R: That was the first time you ever held a gun? G-42: Yeah. Never had a gun so I was kind of happy. R: What kind was it? G-42: It was a little thirty eight the one that revolve. I use to try to go on the bus with it and I use to just carry it for protection but I never had to use it to protect myself $R$ : What, you say you was carrying it for protection. Do you know what you was protecting yourself from? G-42: Nothing. ... That's what I was beginning to figure out I was like "yo I don't need a gun." I be carrying this heavy thing and I don't even need it. If anything it would cause me to get into more trouble, than bring me trouble. . . I brought myself more trouble with it cause I endanger myself ever time I have it on me I see a cop I get kind of nervous I be like "damn I wonder if he know I got this joint on me?" Or, or how about if I even if I'm on the train cause $I$ hear stories yo word yo this nigga took my chain on the train yo psss. Next thing you be like I dare a nigga try to take my shit cause I ain't having it boy I let that nigga know "bloow bloow" I kind of wanted the gangster, I was on the 
gangster mentality for a little while I'm kind of glad I grew out of it. R: With that gun it kind of like gave you .... G-42: Yeah. I went places I wouldn't go, I did, I felt more bolder I would hop a cab with no reason I be like yo I could get anywhere I want to go with this. "This is my Visa."

Physical and social locations also present reasons for concern about one's personal safety. Street corners, subway and bus stops, corner stores, night clubs, house parties, and certain buildings were all mentioned as places where conflict is likely to escalate into violence or evening shootouts. According to our subjects, safety in most settings was uncertain and, therefore, "being prepared" for the worst was important. Facing a gun or other type of violent situation seemed inevitable to many of our subjects.

Interviewer W: Why did you do what you did? G-38: With the gun? W: Yeah. G-38: To protect myself. To protect my peers. W: What were you thinking at the time? G-38: I say we going to this club. Whatever happens, happens. Let's just be ready because people ain't fighting no more like I said. Everybody shooting and I'm not trying to get shot for nothing. For nobody. I don't got no problems with nobody. I'm very humble.

Popular culture has served as a transmitter, amplifier, and interpreter of gunrelated violence. ${ }^{160}$ The celebration of gun possession as a symbol of safety and power is commingled with the dress and speech codes that characterize the behaviors and contexts where violence carries a positive value. This includes conceptions of manhood that place a high value on the willingness to "take a bullet" or otherwise engage in acts of extreme violence. ${ }^{161}$

\section{Self-defense or Protection}

Much of the recent survey-based research has shown that offenders and high school students alike report "self-defense" as the most important reason for carrying firearms. ${ }^{162}$ "Self-defense" has a number of different meanings, including defense against other youth in increasingly hostile and unsafe environments, as well as self-defense from law enforcement officials during the course of illegal activity. ${ }^{163}$ Our subjects provided examples of how weapons were needed for protection and self-defense, what "self-protection" meant to them, and alternative means of avoiding violent situations.

Interviewer R: How did you use to feel when you had a gun? G-41: Had a gun? ...

[W]hen I felt, when I had a gun I felt ... if anything come up I'll be able to protect

myself And if I want to get some money I go get some.

160. Michel Marriott, Hard-Core Rap Lyrics Stir Black Backlash, N.Y. TIMES, Aug. 15, 1993, at A1, A42.

161. Bob Herbert, Kids Know the Real Deal, N.Y. TIMES, Feb. 6, 1994, at § 4, 17.

162. LH Research, supra note 1, at 12; David Kennedy, Guns and Youth: Disrupting the Market (1993) (unpublished manuscript, on file with the John F. Kennedy School of Government, Harvard University); SHELEY \& WRIGHT, supra note 113, at 67. Defense of "self" seems to be recurrent theme is the stories of young inner-city males. See Fagan \& Wilkinson, supra note 9; Anderson, supra note 5, at 89-92; Donald Black, Crime as Social Control, 48 AM. SOC. REv. 34, 35-38 (1983).

163. JAMES D. WRIGHT \& PETER H. ROSSI, ARMED AND CONSIDERED DANGEROUS: A SURVEY OF FELONS AND THEIR FIREARMS 14-15 (expanded ed. 1994). 
All thirty subjects included in the analysis mentioned either "protection" or "defense" of self, peers, family members, and girls. Subjects perceived a variety of sources of attack on self: for example, identity or status attacks, attacks on their physical well-being, attacks on their material possessions, attacks on their relationships with others, and attacks on their freedom from incarceration. Many subjects talked about the dual role that guns played for them: as a means of protection and as a means of facilitating robberies.

Interviewer R: So after that did guns become a repeated thing in your life dealing with
guns like I mean you still carry a gun now and I mean so now you carry a gun for
what protection? G-44: Protection. R: You have beef what? G-44: For protection or
if like or if you want to do robberies and stuff. I mean I don't rob people on the
street and stuff like that. I'm talking about some big money type project. R: Drug
dealers? G-44: Yeah. Yeah.

Gun use for "protection" among individuals heavily involved in hustling or drug selling was very common. The need for "protection" often followed some type of violent conflict or being victimized.

Interviewer W: After the fight did you do anything extra to protect yourself? G-32: In ways. I may, I may have like ...., just to be on the safe side I might have carried my joint down with me. W: Was it necessary to do that? G-32: Yeah. W: Why was it necessary to do anything extra. G-32: 'Cause after I came out I had a feeling that I was gonna see this kid again. Just for the simple ass whipping he caught I felt he was gonna come back and blast me. [Later in the interview] W: After the shootout did you do anything extra to protect yourself? G-32: Yeah. Everyday after that day. W: Why was it necessary to do that? G-32: 'Cause I didn't want to be in that position again of being caught unprepared. Of being stop without a ghat. Being near fucking death is not the way. I don't fucking tell nobody pack a gun, but if you feel like your life is definitely in that path yo, pack on. Throw them guns in the air.

Another subject had a similar experience.

Interviewer M: After the fight you did anything extra to protect yourself? G-56: Oh yes, no doubt, no doubt I'm saying. The only thing I did was to get my gun. M: Why was it necessary to do that? G-56: Why? 'Cause you never know who the next man, what's on the next man mind. You don't know what he gon do to you. Got to worry 'bout the man creep up on you, busting you first.

\section{E. How Guns have Changed the Script}

The presence of weapons may alter the scenarios that govern conflicts and the natural rules of their resolution. Repeatedly, subjects described how things have changed on the street and how guns have taken over in handling beefs or conflicts. Weapons, especially guns, represent a quick and oftentimes final resolution to conflicts. One subject described the continuum of weapons available on the street and how situations are managed with each type of weapon. His description supports the notion that there has been a historical change and that the "interaction order" has been altered by guns. The outcome of these violent events is often perceived as justified or deserved because the other actor made the wrong move or played out the situation in the wrong way.

Interviewer $\mathrm{M}$ : All right. What about knives and bottles and stuff like that. What kind of code defines these situations? G-56: Yo anything you use you ain't got no weapon if it's a bottle crack, if if it could hurt your opponent I'm saying, for you to 
take him out for he gon take you out, do what you got to do. Crack the bottle, stick him in his neck, do ever. Knife, if you got to stab a man to death I'm saying, fear for your life, you got to handle it. M: So it's always to say that it's expected that that a guy uses gun to handle his beef? G-56: Yes. It was like that now. See you was back in ' 83 be a fair a fair fight, hand to hand, but it ain't like that no more. As a old, as the years get older the more the world get violent. M: All right. Let's say you and this guy arguing and he he flash a gun what you gon do? G-56: Well. If I, if I know he got to draw me first I'm saying, I'm say to him talk my way out of it I'm saying. As soon as he turn his back on me that's the wrong move, 'cause I'm gon put one right in his head. I'm gon make sure I empty the whole clip. M: So that's what you suppose to do in that situation? G-56: No doubt. Talk your way out until you I'm saying til' he let down his guard. And then you do what you got to do 'cause you can't let the man live, 'cause yo if man pull a gun on you and let you live he a fool. He deserve to die.

Guns are also the most efficient route to obtaining money or material possessions by illegal means. Accordingly, gun homicides by adolescents reflect a variety of social learned cues motivating the use of weapons. First-hand accounts offer a number of motivations for carrying weapons.

Interviewer M: All right. Who's carrying these guns in your neighborhood like ah what's the ages? . . G-59: [L]ike fifteen to to at least twenty-five, twenty-four. M: For what? Why they carry ... why they got that? G-59: For they got they got a little a lot of beefs going around and a lot lot of bad reputation they like they they need that gun "cause so much dirt they did since . . . buying the gun they do mad dirt just because they have a gun. They got to put the use for it or is to be robbing somebody, showing it out, shooting it out, or just having a victim to shoot him.

If a gun is available, these accounts suggest that it will be the weapon of choice, since it maximizes the possibilities of surviving or managing a violent situation.

VII

\section{IMPLICATIONS FOR PREVENTION AND INTERVENTION}

For many adolescents in urban areas, violence has had a pervasive influence on their social and cognitive development. ${ }^{164}$ Coupled with high adolescent mortality and firearm injury rates, the presence of firearms in their immediate social contexts perpetuates their perceptions of risk and danger in the most common activities of everyday life. Even when not immediately present, the diffusion of violence and danger through popular culture and urban "legends" enhances the perceptions of personal risk. Rituals of mourning and burial, whether real or mythologized, have become cultural touchstones that are reinforced and internalized in normative beliefs and attitudes about the inevitability of violence. Guns have become an important part of the discourse of social interactions, with both symbolic meaning (power and control) as well as strategic importance. Expressions of shortened life expectancies reflect processes of anticipatory socialization based on the perceived likelihood of victimization from lethal violence. Conversely and perversely, carrying firearms

164. John E. Richter \& Pedro Martinez, The NIMH Community Violent Project: I. Children as Victims of and Wimesses to Violence, PSYCHIATRY: INTERPERSONAL \& BIOLOGICAL PROCESSES, Feb. 1993, at 7. 
seems to enhance feelings of safety and personal efficacy among teenagers. ${ }^{165}$ The result is a developmental "ecology of violence," where beliefs about guns and the dangers of everyday life may be internalized in early childhood and shape the cognitive frameworks for interpreting events and actions during adolescence. In turn, this context of danger, built in part around a dominating cognitive schema of violence and firearms, creates, shapes and highly values scripts skewed toward violence. In turn, it also underscores the central role of guns in achieving the instrumental goals of aggressive actions or defensive violence in specific social contexts.

Interventions that adopt this perspective should naturally focus on the development of behavioral scripts, the contingencies within scripts that lead to violence, and the role of firearms in both scripts themselves and the contingencies that evoke them. Focusing on the role of guns within scripts assumes that guns may alter scripts in several ways. For example, guns may change the contingencies and reactions to provocations or threats, and change strategic thinking about the intentions and actions of the other person in the dispute. The presence of guns in social interactions may also produce "moral" judgments that justify aggressive, proactive actions. Accordingly, the development of interventions should be specific to the contexts and contingencies of gun events, rather than simply interpersonal conflicts or disputes.

A variety of conflict-resolution and violence prevention curricula have been developed that focus on social competence, problem-solving, and anger management skills. Many are school-based, focusing on the development of an awareness of violence problems and attitudes about the desirability of violence to solve conflicts. ${ }^{166}$ These classroom-based preventive efforts also focus on self-esteem, co-morbid problem behaviors such as substance use, and techniques for problem solving and conflict resolution. Evaluations suggest that these efforts often improve students' social skills as measured by verbal responses to hypothetical conflict situations about the self-reported likelihood of violent behavior. ${ }^{167}$

One reason for the limited success of these efforts is the limited range of situational contexts and motivations implicit in the violent events they address. Few directly address the contexts in which firearms are present, and the potential effects of firearms in the unfolding of disputes. For example, scripts involving firearms often are effected under conditions of angry arousal and intensified emotional states. ${ }^{168}$ Decisionmaking behaviors modeled in classrooms may not anticipate the changes in cognition that occur under these

165. LH Research, supra note 1, at 10,12; SHELEY \& WRIGHT, supra note 113, at 67.

166. See, e.g., DEBORAH PROTHROW-STITH, DEADLY CONSEQUENCES 173-75 (1991).

167. Devon D. Brewer et al., Preventing Serious, Violent and Chronic Juvenile Offending: $A$ Review of Evaluations of Selected Strategies in Childhood, Adolescence, and the Community, in A SOURCEBOOK ON SERIOUS, VIOLENT AND CHRONIC JUVENILE OFFENDERS 73-74 (J.C. Howell et al., eds., 1995).

168. Jeffrey Fagan \& Deanna Wilkinson, The Function of Adolescent Violence, in VIOLENCE IN AMERICAN SCHOOLS (Delbert S. Elliott \& Beatrix Hamburg eds., forthcoming 1997) (manuscript on file with author); Wilkinson et al., supra note 151. 
conditions of emotional and physiological arousal. And the early reports from our research suggest that in many cases, firearms introduce complexity in decisionmaking introduced by the actions of third parties, or the longstanding nature of disputes that erupt periodically over many months. In other cases, firearms simply trump all other logic.

Preventive interventions must address the growing reality of firearms in the environmental contexts of development, and the internalization of firearms in the development of scripts. Firearms present a level of danger-or strategic certainty-that is unequaled in events involving other weapons or in "fair fights." Interventions should be specific to developmental stages. At early developmental stages, preventive efforts must recognize that for many youngsters with high exposure to lethal violence, the anticipation of lethal violence influences the formation of attitudes favorable to violence and scripts that explicitly incorporate lethal violence. At later developmental stages, the incorporation of strategic violence via firearms alters the course of disputes and narrows options for non-violent behavioral choices.

Classroom methods rely on methods that fail to approximate the conditions on the street where conflicts unfold, including those where guns are present. ${ }^{169}$ They fail to address the role of bystanders and other contextual factors, and do not incorporate the cognitive and emotional states of the disputants. They do not recognize the social embeddedness of disputants in peer networks where the presentation of self carries enormous weight that outweighs other forms of self perception and status. ${ }^{170}$ These curricula do not incorporate the strategic dimension that firearms introduce into the decisionmaking of disputants. They do not recognize how violent discourse often can translate into violent action, and that violence as a symbol often is transformed into violence as substantive action designed to redress grievances or protect one's physical person.

These attributes of conflict, including the presence of guns and their effects on cognition and decisionmaking, should inform the design of preventive efforts and interventions. Contingencies in a variety of contexts should be included: schools, parties, street corner life, the workplace, and in dating situations. The within-event contingencies suggest that interventions be built around stages and sequences of actions, as well as the scripts that individuals bring to events. Firearms can profoundly alter the event dynamics of disputes, and should be explicitly incorporated into prevention activities. Interventions for adolescents should include theater and role play, and employ methods where facilitators "unpack" the stages of events in contexts where the provocative and steering behaviors of bystanders and other third parties are included. Efforts to increase the salience of the training events are needed through provocation and arousal of participants to simulate the fear, anger, and complexity of disputes or

169. See, e.g., D. Bretherton et al., Dealing with Conflict: Assessment of a Course for Secondary School Students, 28 AUSTRALIAN PSYCHOL. 105-111 (1993); D. Webster, The Unconvincing Case for School-Based Conflict Resolution Programs for Adolescents, 12 HEALTH AFFAIRS 126-141 (1993).

170. Anderson, The Code of the Streets, supra note 5, at 86-92. 
situations where firearms are present. Interventions also should teach noncombatants how their behaviors as bystanders can increase the risks of lethal violence for young men facing off on the street. Interventions for younger children should increase their recognition of their own (and others') scripts.

Evaluations of these efforts also should include a focus on events to determine the effects of interventions on decisionmaking and event outcomes. Evaluations that address only attitudes about violence or self-reports of likely violent behaviors risk validity threats from social desirability in students' responses, and short-term follow-ups that do not take into account intervening experiences. Incremental gains from interventions can be detected when interaction patterns are analyzed to assess how scripts may be altered, events may be analyzed in a new or different framework, and ultimately how the risks and likelihood of violence can be reduced.

\section{VIII \\ CONCLUSION}

This article has attempted to examine the role of firearms in violent events among adolescent males in the inner city. By comparing the pattern of firearm use among adolescents across historical periods, factors could be identified that seem to have contributed to the recent escalation and the present day crises. Structural changes in communities and neighborhoods have preceded the rise in adolescent weapons use, as have the nature and density of illegal markets as well as the availability and firepower of weapons themselves. These changes have reshaped both the social controls and street networks that in the past regulated violent transactions. There are a number of antecedents and factors contributing to the current crisis that we are only beginning to understand.

Explanations of firearms use among adolescents requires several levels of analysis: the sources of weapons, the nature of everyday life that gives rise to conflicts that turn lethal, the "scripts" of adolescent life that lead to escalation (and the factors that underlie those scripts), the motivations for carrying/using weapons, and the role of weapons in the decisionmaking processes of adolescents when they engage in disputes or even predatory violence. The presence of firearms is not an outcome of other processes, but part of a dynamic and interactive social process where they alter the decisions leading to violence and the outcomes of violent events.

Using an event-based approach, the article suggests a conceptual framework for explaining interactions that involve adolescents and firearms. This approach does not deny the importance of the individual attributes that bring people to situations, but recognizes that once there, other processes shape the outcomes of these events. Events are analyzed as "situated transactions," including rules that develop within specific contexts, the situations and contexts where weapons are used, the motivations for carrying and using weapons, and the personality "sets" of groups where weapons are used. There are "rules" that govern how disputes are settled, when and where firearms are used, and the significance of 
firearms within a broader adolescent culture. Violence "scripts" often are invoked. These scripts may limit the behavioral and strategic options for resolving disputes, and the presence of firearms influences which scripts are invoked. Several theories from criminology, cognitive psychology, symbolic interactionism, and social psychology are brought to bear on the issue of the study of violent events. Because violence generally is a highly contextualized event, we have discussed the ways in which specific contexts shape decisions by adolescents to carry or use weapons, and how scripts are developed and shaped through diffusion within closed social groups. Finally, to advance the study and to prevent violent events involving adolescents, interventions, research and methodological innovation must reflect specificity about guns and their effects on cognition, moral development, and behavior. 